\title{
Potensi Cendawan Asal Hydrilla verticillata Sebagai Pengendali Hayati Fusarium oxysporum dan Ganoderma boninense
}

\author{
Fungi from Hydrilla verticillata as Potential Biological Control \\ Agents of Fusarium oxysporum and Ganoderma boninense
}

\author{
ASTRI ARIYANI, NAMPIAH SUKARNO*, SRI LISTIYOWATI \\ Departemen Biologi, Fakultas MIPA, Institut Pertanian Bogor, Kampus IPB Dramaga, Bogor 16680
}

Diterima 12 Mei 2019/Disetujui 24 Juli 2019

\begin{abstract}
Hydrilla verticillata is an aquatic weed, can build symbiosis and also become a substrate of freshwater fungi. Some of freshwater fungi that live in association with $\mathrm{H}$. verticillata are pathogenic fungi which were potentially used as controller for Fusarium oxysporum and Ganoderma boninense. The use of pathogenic fungi as a biocontrol is not consistent in the field. Therefore, this research aimed to find new fungus candidates that are stronger and more consistent in controlling pathogenic fungi. Freshwater fungi were isolated from $\mathrm{H}$. verticillata. Identification was based on morphological characters. Molecular analysis was carried out for freshwater fungi which had the highest inhibition percentage to pathogenic fungi. The antagonism test was conducted by dual culture method. The mechanism of interaction of hyphae was observed under a microscope. Freshwater fungi was derived from $\mathrm{H}$. verticillata stem are Aspergillus section flavi, Gliomastix sp., and Talaromyces sp. Antagonism test results showed that all fungi could inhibit the growth of pathogenic fungi. Based on molecular analysis used ITS region showed Talaromyces sp. could not identify to the level of species so that additional genes were required, namely beta-tubulin gene, in order to further identify Talaromyces sp.
\end{abstract}

Key words: Hydrilla verticillata, Fusarium oxysporum, Ganoderma boninense, antagonist test

\section{PENDAHULUAN}

Hydrilla verticillata ialah tanaman yang hidupnya terendam di dalam air, memiliki kemampuan tumbuh yang cepat, dapat hidup pada berbagai kondisi $\mathrm{pH}$, sedikit cahaya matahari, dan nutrisi (Langeland 1996; Alix et al. 2009). Hydrilla verticillata dapat bersimbiosis dan juga menjadi substrat dari cendawan air tawar. Beberapa contoh cendawan tersebut ialah Botryosporium sp., Cercosporidium sp., Chaetophoma sp., Diplodia sp., Pyrenochaeta sp. sebagai patogen, sedangkan Cladosporium sp. dan Penicillium sp. dilaporkan sebagai saprob (Shabana dan Charudattan 1996). Cendawan patogen yang hidup di air atau yang berasosiasi dengan $H$. verticillata, berpotensi sebagai pengendali cendawan patogen (Shearer 2016).

Fusarium oxysporum ialah cendawan patogen penyebab penyakit layu fusarium. Penyakit ini menjadi masalah utama dan merugikan pada tanaman pisang terutama di Indonesia (Daryanto 2004). Penyakit layu fusarium sulit dikendalikan karena memiliki struktur bertahan berupa klamidospora. Klamidospora ialah

*Penulis korespondensi:

E-mail: ipi.sukarno@gmail.com spora aseksual berdinding tebal yang dihasilkan oleh hifa atau konidium. Klamidospora dapat bertahan di tanah bekas tanaman inang yang sudah mati sebagai saprofit dalam waktu tiga sampai empat tahun (Nelson 1993).

Ganoderma boninense ialah cendawan patogen penyebab busuk pangkal batang (BPB) di perkebunan kelapa sawit di Indonesia dan Malaysia. Cendawan patogen ini menyerang tanaman kelapa sawit muda maupun tua (Susanto et al. 2013). Penyakit BPB yang menyerang kelapa sawit ini sulit untuk dikendalikan karena penyakit BPB cepat berkembang dan sulit dideteksi pada awal perkembangannya serta dapat menyebabkan tanaman kelapa sawit menjadi layu dan mati dalam waktu relatif singkat (Ginting dan Maryono 2012).

Berbagai upaya telah dilakukan untuk mengendalikan penyakit BPB dan layu fusarium, baik melalui perlakuan fisik, kimia maupun biologis. Penggunaan fungisida sintetik dapat menghambat pertumbuhan $F$. oxysporum dan G. boninense, akan tetapi residu fungisida yang dihasilkan juga berdampak buruk bagi lingkungan (Sa'id 1994). Penanggulangan menggunakan mikroorganisme antagonis sebagai pengendali hayati merupakan cara yang lebih baik karena ramah lingkungan, akan tetapi 
penggunaan mikroorganisme sebagai pengendali cendawan patogen hingga saat ini belum konsisten di lapangan (Priwiratama et al. 2014). Penelitian ini bertujuan untuk mengisolasi cendawan yang berasosiasi dengan $H$. verticilliata yang berpotensi sebagai agen pengendali unggul terhadap cendawan patogen $F$. oxysporum dan $G$. boninense.

\section{BAHAN DAN METODE}

Bahan Penelitian. Bahan-bahan yang digunakan ialah $H$. verticilliata, cendawan patogen uji, Potato Dextrose Agar (PDA), larutan shears (potasium asetat, akuades, gliserin, dan etanol 95\%), etanol 70\% dan $75 \%, \mathrm{NaOCl} 1 \%$, dan kloramfenikol $500 \mathrm{mg}$.

Isolasi Cendawan Asal Hydrilla verticilliata. $H$. verticilliata pada penelitian ini diperoleh dari Danau Wiratama Taman Buah Mekarsari, Cileungsi, Indonesia. Isolasi cendawan pada $H$. verticilliata. merujuk metode yang dilaporkan oleh Filip et al. (2003) dengan modifikasi. Bagian $H$. verticilliata yang diisolasi ialah daun dan batang $H$. verticilliata sehat dan sakit. Daun dan batang $H$. verticilliata sehat dan sakit dipotong dengan ukuran $\pm 0.5 \mathrm{x}$ $0.5 \mathrm{~cm}$. Sampel disterilisasi permukaan dengan menggunakan etanol $75 \%$ selama 30 detik, $\mathrm{NaOCl}$ 1\% selama 3 menit, dan etanol $70 \%$ selama 1 menit secara berurutan. Pembilasan dengan akuades steril sebanyak 3 kali dilakukan pada setiap perpindahan proses sterilisasi. Daun dan batang $H$. verticilliata yang sudah disterilisasi permukaannya diletakkan pada kertas saring steril secara terpisah selama semalam dan diletakkan pada medium PDA yang mengandung antibiotik kloramfenikol. Inkubasi dilakukan selama 7 hari pada suhu $28 \pm 2^{\circ} \mathrm{C}$. Isolat yang tumbuh dimurnikan dengan memindahkan ke medium PDA segar tanpa antibiotik.

Identifikasi Morfologi Cendawan Asal Hydrilla verticilliata. Identifikasi morfologi mengacu pada kunci identifikasi Seifert et al. (2011). Karakteristik morfologi yang digunakan untuk identifikasi morfologi di antaranya sekat pada hifa, struktur konidiofor, sel konidiogen, dan karakteristik spora.

Uji Antagonisme Cendawan Asal Hydrilla verticilliata dengan Cendawan Patogen. Setiap isolat cendawan hasil isolasi dari $H$. verticilliata diuji sifat antagonisnya terhadap cendawan patogen yaitu $F$. oxysporum dan $G$. boninense menggunakan metode biakan ganda (dual culture) (Skidmore dan Dickinson 1976). Isolat cendawan $(\varnothing 1 \mathrm{~cm})$ diletakkan pada medium PDA dengan jarak $3 \mathrm{~cm}$ dari tepi cawan Petri, kemudian cendawan patogen $(\varnothing 1 \mathrm{~cm})$ diletakkan berhadapan dengan isolat cendawan dengan jarak $3 \mathrm{~cm}$ dari isolat cendawan uji. Inkubasi dilakukan selama pertumbuhan cendawan kontrol yaitu cendawan patogen tumbuh memenuhi cawan Petri. Persentase penghambatan terhadap pertumbuhan cendawan patogen oleh isolat cendawan uji dihitung berdasarkan rumus yang dilaporkan Fokkema (1978) sebagai berikut:

$$
\text { Penghambatan pertumbuhan }(\%)=\frac{\mathrm{J}_{1}-\mathrm{J}_{2}}{\mathrm{~J}_{1}} \times 100 \%
$$

Keterangan:

$\mathrm{J}_{1}=$ Jari-jari koloni cendawan patogen yang tumbuh ke arah berlawanan dengan tempat isolat cendawan uji

$\mathrm{J}_{2}=$ Jari-jari koloni cendawan patogen yang tumbuh ke arah tempat cendawan uji

Mekanisme Antagonis Cendawan Asal Hydrilla verticilliata dengan Cendawan Patogen. Pengamatan mekanisme antagonis dilakukan secara mikroskopis dengan cara mengambil hifa di daerah kontak cendawan uji dan patogen, kemudian diletakkan di atas gelas objek yang telah diberi larutan shears kemudian ditutup menggunakan gelas penutup dan diamati di bawah mikroskop binokuler. Mekanisme interaksi yang terjadi antara cendawan patogen dan isolat cendawan uji didasarkan pada kriteria yang dilaporkan oleh Porter (1942), Skidmore dan Dickinson (1976) yaitu kompetisi, antibiosis, dan parasitisme.

Identifikasi Molekuler Cendawan Asal Hydrilla verticilliata. Identifikasi molekuler hanya dilakukan pada isolat yang memiliki persentase hambatan tertinggi terhadap F. oxysporum dan G. boninense. Identifikasi molekuler menggunakan sekuen daerah ITS rDNA dengan primer ITS 1 dan ITS 4. Ekstraksi DNA menggunakan ZR Fungal Bacterial DNA Kit (Zymo Research). Amplifikasi daerah ITS rDNA dengan teknik PCR dilakukan menggunakan primer ITS 1 (forward) (5'-TCCGTAGGTGAACCTGCGG-3') dan ITS 4 (reverse) (5'-TCCTCCGCTTATTGATATGC-3') (White et al. 1990). DNA hasil amplifikasi disekuensing menggunakan jasa perusahaan $1^{\text {st }}$ Base, Malaysia menggunakan primer ITS 1 dan 4. Karakter molekuler berupa urutan basa nukleotida, dianalisis menggunakan perangkat lunak ChromasPro versi 1.7.5 dan analisis homologi menggunakan program BLAST-N di situs (www.ncbi.nlm.nih.gov). Sekuen yang dihasilkan kemudian disimpan di GeneBank. Sebanyak 52 sekuen pembanding diperoleh dari GeneBank, 1 di antaranya ialah outgroup (Tabel 1). Seluruh sekuen disejajarkan dengan menggunakan perangkat lunak Muscle dalam MEGA versi 5. Analisis filogenetik menggunakan metode Maximum Likelihood dengan 1000 bootstrap dilakukan dalam program MEGA versi 5.2 (Tamura et al. 2011). 
Tabel 1. Daftar spesies yang digunakan dalam analisis filogenetik beserta nomor aksesi GenBanknya

\begin{tabular}{|c|c|c|c|c|}
\hline Ingroup/outgroup & No & Nama spesies & Nomor sampel & Nomor aksesi \\
\hline Ingroup & 1 & Talaromyces pinophilus & $\mathrm{MC}$ & MF683084 \\
\hline Ingroup & 2 & Talaromyces pinophilus & H6 & KF751644 \\
\hline Ingroup & 3 & Talaromyces pinophilus & $\mathrm{L} 22$ & JX684010 \\
\hline Ingroup & 4 & Talaromyces pinophilus & DI 16-141 & LT558963 \\
\hline Ingroup & 5 & Talaromyces pinophilus & $1-95$ & FJ795356 \\
\hline Ingroup & 6 & Talaromyces pinophilus & H4284 & GU595046 \\
\hline Ingroup & 7 & Talaromyces sayulitensis & DTO 245H1 & KJ775713 \\
\hline Ingroup & 8 & Talaromyces sayulitensis & DTO 245H2 & KJ775714 \\
\hline Ingroup & 9 & Talaromyces sayulitensis & DTO $245 \mathrm{H} 3$ & KJ775715 \\
\hline Ingroup & 10 & Talaromyces pinophilus & CBS 631.66 & JN899382 \\
\hline Ingroup & 11 & Talaromyces apiculatus & CBS 312.59 & JN899375 \\
\hline Ingroup & 12 & Talaromyces aculeatus & NFML CH62 5DcA & KM458839 \\
\hline Ingroup & 13 & Talaromyces thailandensis & CBS 133147 & JX898041 \\
\hline Ingroup & 14 & Talaromyces funiculosus & CBS 272.86 & JN899377 \\
\hline Ingroup & 15 & Talaromyces macrosporus & CBS 317.63 & JN899333 \\
\hline Ingroup & 16 & Talaromyces purpureogenus & CBS 286.36 & JN899372 \\
\hline Ingroup & 17 & Talaromyces flavus & CBS 225.66 & JN899395 \\
\hline Ingroup & 18 & Talaromyces indigoticus & CBS 100534 & JN899331 \\
\hline Ingroup & 19 & Talaromyces rubicundus & CBS 342.59 & JN899384 \\
\hline Ingroup & 20 & Talaromyces galapagensis & CBS 751.74 & JN899358 \\
\hline Ingroup & 21 & Talaromyces intermedius & CBS 152.65 & JN899332 \\
\hline Ingroup & 22 & Talaromyces calidicanius & CBS 112002 & JN899319 \\
\hline Ingroup & 23 & Talaromyces duclauxii & CBS 322.48 & JN899342 \\
\hline Ingroup & 24 & Talaromyces derxii & CBS 412.89 & JN899327 \\
\hline Ingroup & 25 & Talaromyces stipitatus & CBS 375.48 & JN899348 \\
\hline Ingroup & 26 & Talaromyces marneffei & CBS 388.87 & JN899344 \\
\hline Ingroup & 27 & Talaromyces angelicus & CNU 100013 & KF183638 \\
\hline Ingroup & 28 & Talaromyces paucisporus & CBM FA 0944 & $\mathrm{AB} 176603$ \\
\hline Ingroup & 29 & Talaromyces viridulus & CBS 252.87 & JN899314 \\
\hline Ingroup & 30 & Talaromyces panamensis & CBS 128.89 & JN899362 \\
\hline Ingroup & 31 & Talaromyces flavus & CBS 310.38 & JN899360 \\
\hline Ingroup & 32 & Talaromyces siamensis & CBS 475.88 & JN899385 \\
\hline Ingroup & 33 & Talaromyces cnidii & DTO 270A4 & KJ775729 \\
\hline Ingroup & 34 & Talaromyces cnidii & DTO 26916 & KJ775727 \\
\hline Ingroup & 35 & Talaromyces cnidii & DTO $269 \mathrm{H} 8$ & KJ775724 \\
\hline Ingroup & 36 & Talaromyces siamensis & DTO 26913 & KJ775726 \\
\hline Ingroup & 37 & Talaromyces euchlorocarpius & CBM FA 0942 & $\mathrm{AB} 176617$ \\
\hline Ingroup & 38 & Talaromyces primulinus & CBS 321.48 & JN899317 \\
\hline Ingroup & 39 & Talaromyces oumae-annae & DTO 180B4 & KJ775710 \\
\hline Ingroup & 40 & Talaromyces oumae-annae & DTO 269E8 & KJ775720 \\
\hline Ingroup & 41 & Talaromyces verruculosus & DTO 129H4 & KJ775698 \\
\hline Ingroup & 42 & Talaromyces verruculosus & DTO $129 \mathrm{H} 5$ & KJ775699 \\
\hline Ingroup & 43 & Talaromyces amestolkiae & DTO 179E4 & KJ775706 \\
\hline Ingroup & 44 & Talaromyces amestolkiae & DTO $179 \mathrm{~F} 1$ & KJ775707 \\
\hline Ingroup & 45 & Talaromyces amestolkiae & DTO 179F6 & KJ775708 \\
\hline Ingroup & 46 & Talaromyces stollii & CBS 408.93 & JX315674 \\
\hline Ingroup & 47 & Talaromyces ruber & DTO193H6 & JX315662 \\
\hline Ingroup & 48 & Talaromyces aurantiacus & CBS 314.59 & JN899380 \\
\hline Ingroup & 49 & Talaromyces muroii & CBS 756.96 & JN899351 \\
\hline Ingroup & 50 & Talaromyces pinophilus & IPBCC. 18.1412 & \\
\hline Outgroup & 51 & Trichocoma paradoxa & CBS 788.83 & JN899398 \\
\hline
\end{tabular}

\section{HASIL}

Isolasi dan Identifikasi Morfologi Cendawan Asal Hydrilla verticilliata. Tiga isolat cendawan berhasil diisolasi. Cendawan tersebut berasal dari batang tumbuhan $H$. verticilliata yang terdiri atas 1 isolat berasal dari batang sehat dan 2 isolat berasal dari batang sakit. Berdasarkan pengamatan mikroskopis, cendawan yang berhasil diisolasi ialah cendawan anamorf yang membentuk hifa septat, menghasilkan konidia, dan konidiofor. Berdasarkan karakteristik morfologi cendawan tersebut ialah Aspergillus kelompok flavi, Gliomastix sp., dan Talaromyces sp. Karakteristik morfologi cendawan disajikan pada Tabel 2 dan Gambar 1,2 , dan 3 .

Uji Antagonisme Cendawan Asal Hydrilla verticilliata dengan Cendawan Patogen. Semua cendawan asal $H$. verticilliata memiliki kemampuan aktivitas penghambatan terhadap pertumbuhan cendawan patogen $G$. boninense dan F. oxysporum. 
Tabel 2. Karakteristik morfologi cendawan asal Hydrilla verticilliata pada medium PDA

Kode isolat Genus Deskripsi

\begin{tabular}{lr}
\hline DKBS & Koloni tumbuh pada medium PDA dengan diameter koloni $17 \mathrm{~mm}$ pada suhu $28 \pm$ \\
kelompok flavi & $2^{\circ} \mathrm{C}$ selama 7 hari, membeledu, permukaan koloni teksturnya agak kasar. Warna \\
& koloni hijau tua dan ketika dibalik berwarna putih kekuningan. Konidiofor \\
& hialin, tidak bersekat. Vesikula membulat. Fialid berbentuk silinder, meruncing \\
& dibagian lehernya, membengkak, lalu meruncing kembali di pangkal. Konidia \\
& hialin, permukaan halus, membulat (4 $2 \mu \mathrm{m})$, tidak bersekat.
\end{tabular}

DLMB1 Gliomastix sp.

Koloni memiliki diameter $18.1 \mathrm{~mm}$ pada suhu $28 \pm 2^{\circ} \mathrm{C}$ selama 7 hari, permukaan koloni mengapas. Warna koloni sebelumnya berwarna putih, setelah itu terdapat kumpulan masa spora berwarna hitam di tengah dan ketika dibalik berwarna putih. Lebar hifa vegetatif $43.7 \mu \mathrm{m}$. Sel konidiogenus monofialid, meruncing di bagian ujung, muncul ke atas permukaan dari lilitan miselium yang membentuk ikatan tali dengan membentuk tekstur granula. Konidiofor memiliki panjang $2095.5 \mu \mathrm{m}$, lebar bawah $163.7 \mu \mathrm{m}$, tengah $126.4 \mu \mathrm{m}$, ujung $86 \mu \mathrm{m}$, tidak bercabang, hialin, berdinding halus. Konidia $(10.3 \mathrm{x}$ $68.7 \mu \mathrm{m}$ ) berantai, membulat, hialin, dinding konidia halus, tidak bersekat.

DLMB2

Talaromyces

sp.
Diameter koloni mencapai $363.6 \mathrm{~mm}$ selama 7 hari pada suhu $28 \pm 2^{\circ} \mathrm{C}$. Miselium muncul di permukaan medium, berwarna kuning pastel dan ketika dibalik berwarna cokelat kemerahan, teksturnya halus hingga membentuk seperti tali. Sporulasi jarang hingga cukup padat, sporulasi dimulai hari ketiga, pada hari keempat belas muncul tetesan eksudat merah. Konidiofor memiliki panjang $24.2 \mu \mathrm{m}$, lebar pangkal konidiofor $1.9 \mu \mathrm{m}$, meruncing di bagian ujung 1.7 $\mu \mathrm{m}$, bercabang lebih dari dua; cabang $(6.9 \times 2.7 \mu \mathrm{m})$; metula $(7.5 \times 3.3 \mu \mathrm{m})$. Fialid berbentuk labu $(10.3 \times 2.9 \mu \mathrm{m})$, meruncing di bagian leher, terdapat tiga hingga empat fialid per metula. Konidia halus, membulat (2.3-3.5 x $2.5-4 \mu \mathrm{m})$, tidak bersekat.

\section{$\overline{\mathrm{DLMB}}=$ batang Hydrilla verticilliata mati; DKBS=batang Hydrilla verticilliata sehat}
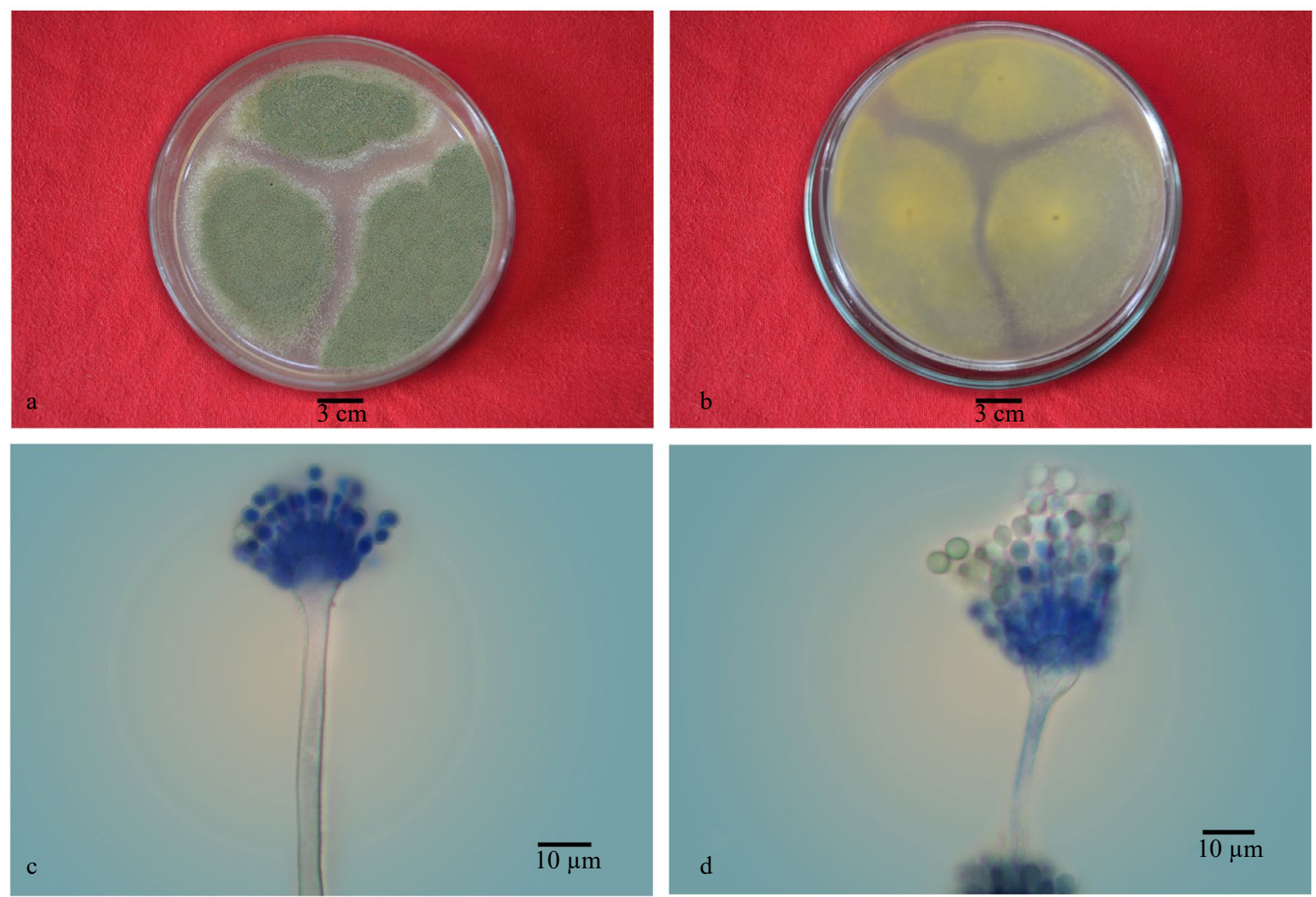

Gambar 1. Koloni Aspergillus sp. 2 pada medium PDA setelah inkubasi selama 7 hari pada suhu $28 \pm 2^{\circ} \mathrm{C}$ (a) tampak belakang (b) mikrograf konidiofor, vesikula membulat hingga bulat (c), metula terdiri dari 2-6 fialid, dan konidium (d) menggunakan pewarna katun biru 
Analisis rancangan acak lengkap (RAL) terhadap persentase penghambatan cendawan asal $H$. verticilliata dengan $F$. oxysporum dan $G$. boninense menunjukkan perbedaan yang signifikan. Berdasarkan analisis Duncan, Talaromyces sp. menghasilkan persentase pengahambatan tertinggi, sedangkan Aspergillus kelompok flavi memiliki persentase penghambatan terendah. Persentase penghambatan yang melebihi $70 \%$ terhadap $G$. boninense maupun F. oxysporum merupakan isolat potensial untuk
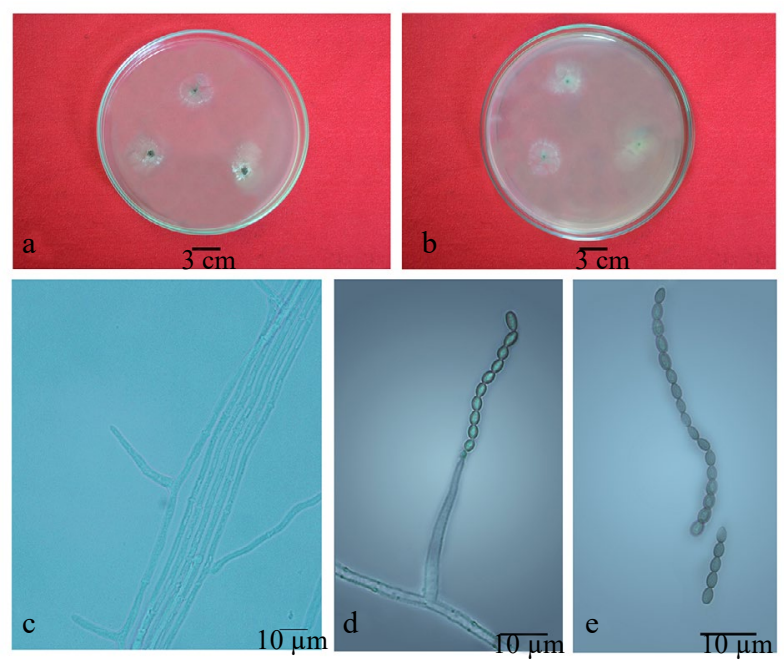

Gambar 2. Koloni Gliomastix sp. inkubasi 7 hari, suhu $28 \pm$ $2^{\circ} \mathrm{C}$ pada medium PDA (a), konidiofor tegak (b), se konidiogen monofialid (c, e), konidia berantai (d)
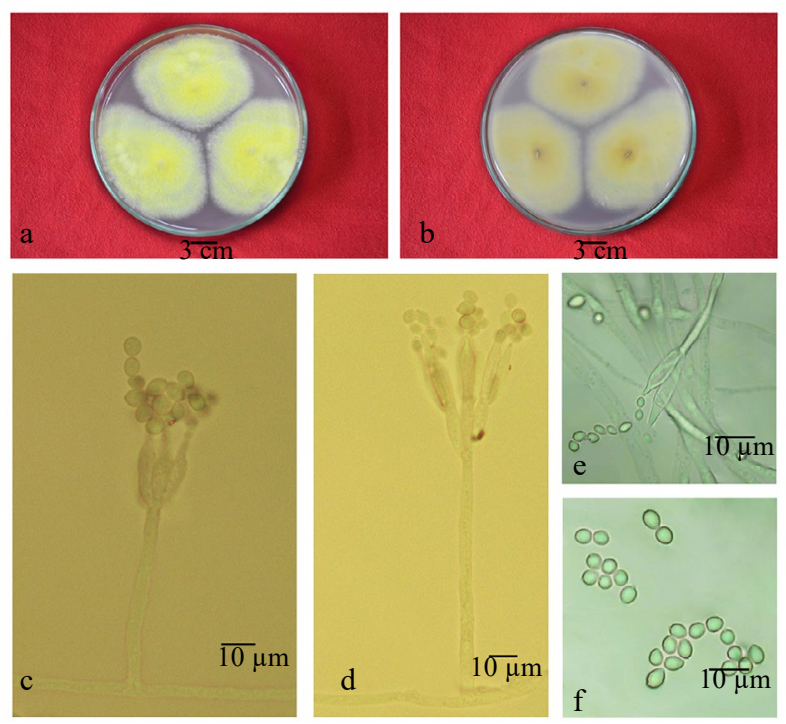

Gambar 3. Koloni Talaromyces sp. inkubasi 7 x 24 jam, suhu 28 $\pm 2^{\circ} \mathrm{C}$ pada medium PDA tampak depan (a), tampak belakang (b). Konidiofor tegak (c), bercabang (d). Konidia berantai (e), permukaan halus, membulat (f) mengendalikan cendawan patogen. Talaromyces sp. memiliki persentase penghambatan sebesar $87.8 \%$ terhadap $G$. boninense dan $87.5 \%$ terhadap F. oxysporum (Tabel 3). Isolat potensial lainnya yang dapat dijadikan sebagai pengendali hayati ialah Gliomastix sp. dengan nilai persentase penghambatan $84.2 \%$ terhadap pertumbuhan $F$. oxysporum dan $70.4 \%$ terhadap G. boninense (Tabel 4). Hasil uji antagonisme Talaromyces sp., Gliomastix sp., dan Aspergillus kelompok flavi terhadap F. oxysporum dan G. boninense disajikan pada Gambar 4 dan 5 .

Mekanisme Antagonis. Hasil pengamatan secara mikroskopis menunjukkan bahwa mekanisme penghambatan Aspergillus kelompok flavi terhadap F. oxysporum menyebabkan struktur hifa cendawan patogen menjadi tidak sehat ditandai dengan permukaan hifa yang kasar (Gambar 6). Pada daerah pertemuan antara cendawan uji dan patogen tidak ditemukan spora $F$. oxysporum akan tetapi banyak ditemukan klamidospora $F$. oxysporum (Gambar 6), sedangkan spora Aspergillus kelompok flavi terlihat mendominasi. Mekanisme penghambatan Gliomastix sp. terhadap $F$. oxysporum menyebabkan hifa keriting (Gambar 7). Penghambatan yang diakibatkan oleh Talaromyces sp. terhadap $F$. oxysporum mengakibatkan terbentuknya klamidospora (Gambar 8) dalam jumlah besar pada daerah pertemuan antara kedua hifa, sebaliknya spora cendawan uji mendominasi pada daerah tersebut. Berdasarkan hasil pengamatan mekanisme penghambatan Aspergillus kelompok flavi terhadap G. boninense secara mikroskopis, menunjukkan hifa cendawan patogen mengalami perubahan struktur, ditunjukkan dengan adanya embelan seperti duri (Gambar 6) dan hifa menjadi keriting (Gambar 6). Mekanisme penghambatan Gliomastix sp. terhadap $G$. boninense yang diamati secara mikroskopis menyebabkan hifa keriting (Gambar 7). Mekanisme penghambatan yang dilakukan oleh Talaromyces sp.

Tabel 3. Penghambatan pertumbuhan cendawan asal Hydrilla verticilliata terhadap Fusarium oxysporum dan Ganoderma boninense

\begin{tabular}{|c|c|c|c|}
\hline \multirow{2}{*}{ Kode isolat } & \multirow{2}{*}{ Genus } & \multicolumn{2}{|c|}{ Hambatan pertumbuhan $(\%)$} \\
\hline & & $\begin{array}{l}\text { Fusarium } \\
\text { oxysporum }\end{array}$ & $\begin{array}{l}\text { Ganoderma } \\
\text { boninense }\end{array}$ \\
\hline$\overline{\mathrm{DKBS}}$ & $\begin{array}{l}\text { Aspergillus } \\
\text { kelompok flavi }\end{array}$ & $63.3^{\mathrm{b}}$ & $44.6^{\mathrm{c}}$ \\
\hline DLMB1 & Gliomastix sp. & $84.2^{\mathrm{a}}$ & $70.4^{b}$ \\
\hline DLMB2 & Talaromyces sp. & $87.5^{\mathrm{a}}$ & $87.8^{\mathrm{a}}$ \\
\hline
\end{tabular}

Angka-angka yang diikuti oleh huruf yang sama pada kolom yang sama tidak berbeda nyata berdasarkan uji Duncan pada taraf kepercayaan $99 \%$

Tabel 4. Hasil BLAST menggunakan sekuen DNA daerah ITS 1, 5.8, ITS 2 rDNA dari cendawan asal Hydrilla verticilliata yang diisolasi dari Danau Wiratama, Taman Buah Mekarsari

\begin{tabular}{lccccccc}
\hline \multirow{2}{*}{ Kode isolat } & \multicolumn{7}{c}{ Hasil BLAST pada situs ncbi } \\
\cline { 2 - 7 } & Skor maksimum & Skor total & Query cover & e value & Persentase kemiripan & Spesies & Nomor akses GeneBank \\
\hline
\end{tabular}




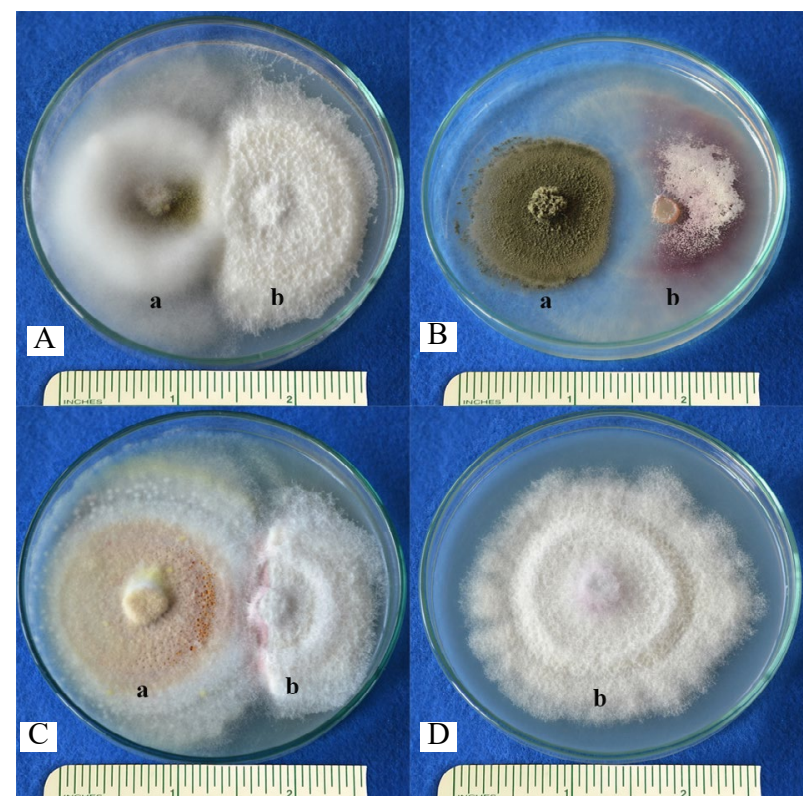

Gambar 4. Uji antagonisme antara cendawan asal Hydrilla verticilliata dengan Fusarium oxysporum pada medium agar-agar dektrosa kentang setelah 14 hari inkubasi pada suhu $28 \pm 2^{\circ} \mathrm{C}$. (A) Aspergillus kelompokflavi, (B) Gliomastix sp., (C) Talaromyces sp., (D) kontrol. (a) Cendawan uji, (b) Fusarium oxysporum

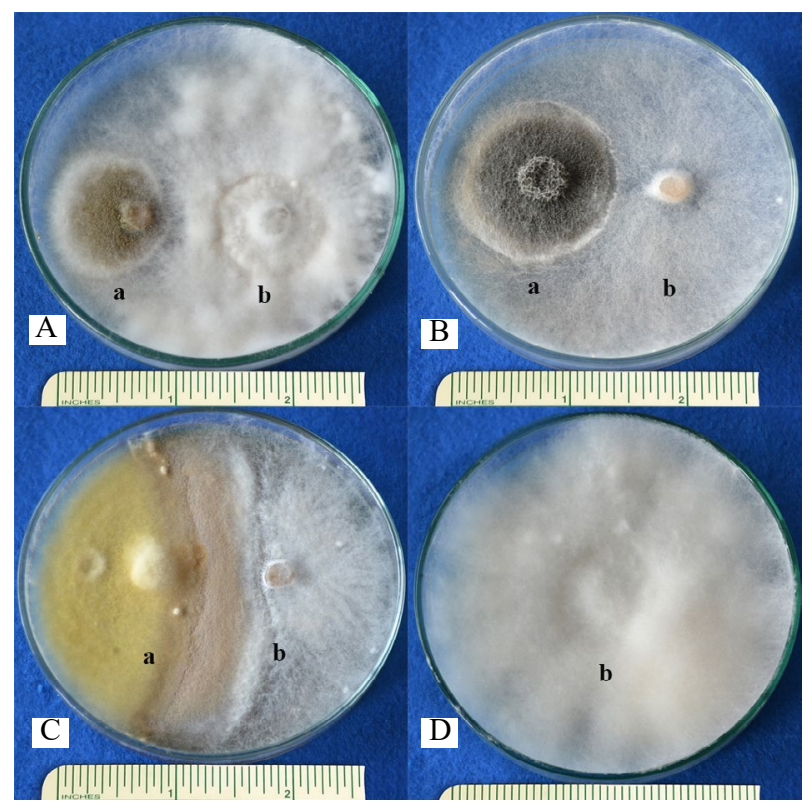

Gambar 5. Uji antagonisme antara cendawan asal Hydrilla verticilliata dengan Ganoderma boninense pada medium agar-agar dektrosa kentang setelah 14 hari inkubasi pada suhu $28 \pm 2^{\circ} \mathrm{C}$. (A) Aspergillus kelompokflavi, (B) Gliomastix sp., (C) Talaromyces sp., (D) kontrol. (a) Cendawan uji, (b) Ganoderma boninense.

terhadap $G$. boninense menunjukkan hifa cendawan patogen ditutupi oleh cendawan uji (Gambar 8).

Identifikasi Molekuler Cendawan Asal Hydrilla verticilliata yang Potensial. Identifikasi molekuler cendawan dilakukan terhadap Talaromyces sp. karena memiliki potensi mengendalikan cendawan

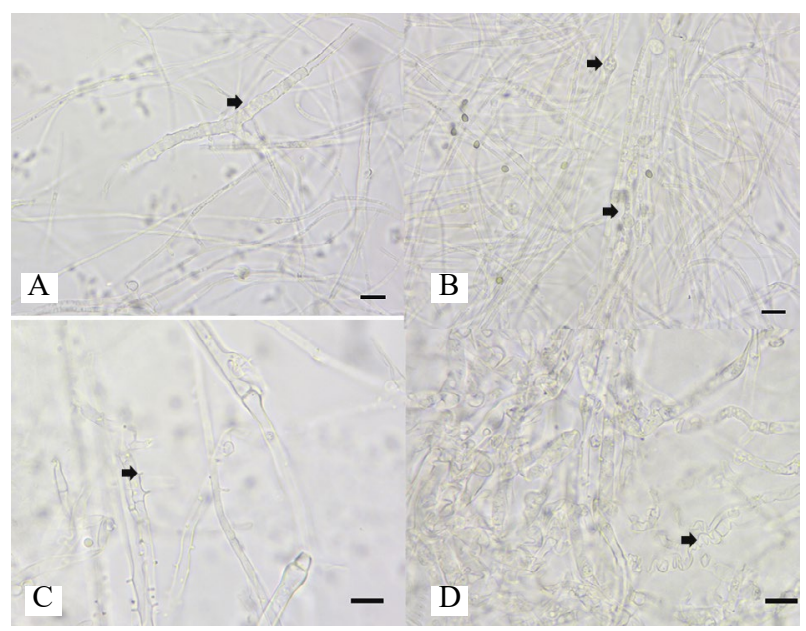

Gambar 6. Mekanisme penghambatan Aspergillus kelompok flavi terhadap Fusarium oxysporum menyebabkan permukaan hifa cendawan patogen kasar (A), terdapat klamidospora $F$. oxysporum (B). Mekanisme penghambatan Aspergillus kelompok flavi terhadap Ganoderma boninense menyebabkan hifa cendawan patogen memiliki embelan seperti duri (C) dan keriting (D). Garis skala $=10 \mu \mathrm{m}$

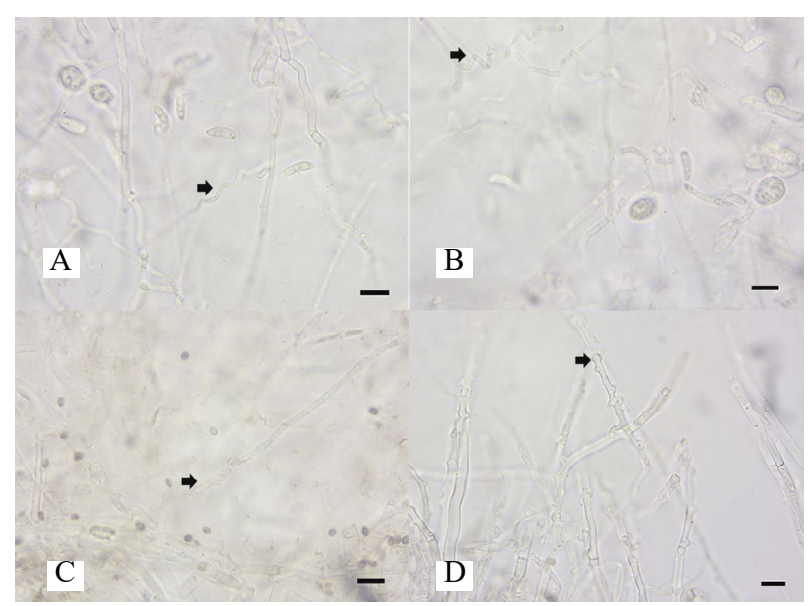

Gambar 7. Mekanisme penghambatan Gliomastix sp. terhadap Fusarium oxysporum menyebabkan hifa keriting (A-B). Mekanisme penghambatan Gliomastix sp. terhadap Ganoderma boninense menyebabkan hifa keriting (C-D). Garis skala $=10 \mu \mathrm{m}$

patogen $F$. oxysporum dan G. boninense. Analisis filogenetik pada daerah ITS menghasilkan pohon dengan metode Maximum Likelihood (ML), model perhitungan Tamura-3 parameter dengan distribusi Gamma Invariant menggunakan perangkat lunak MEGA. Berdasarkan analisis BLAST terhadap spesies pembanding di GeneBank, Talaromyces sp. memiliki kemiripan 99\% dengan T. aculeatus (Tabel 4). Hasil analisis pohon filogenetik menunjukkan Talaromyces sp. membentuk spesies kompleks dengan T. aculeatus, T. apiculatus, dan T. thailandensis dengan nilai bootstrap di bawah 50\% (Gambar 9). Rendahnya nilai bootsrap dan terbentuknya spesies kompleks pada clade tersebut menandakan bahwa cendawan hanya dapat diidentifikasi hingga tingkat genus. 


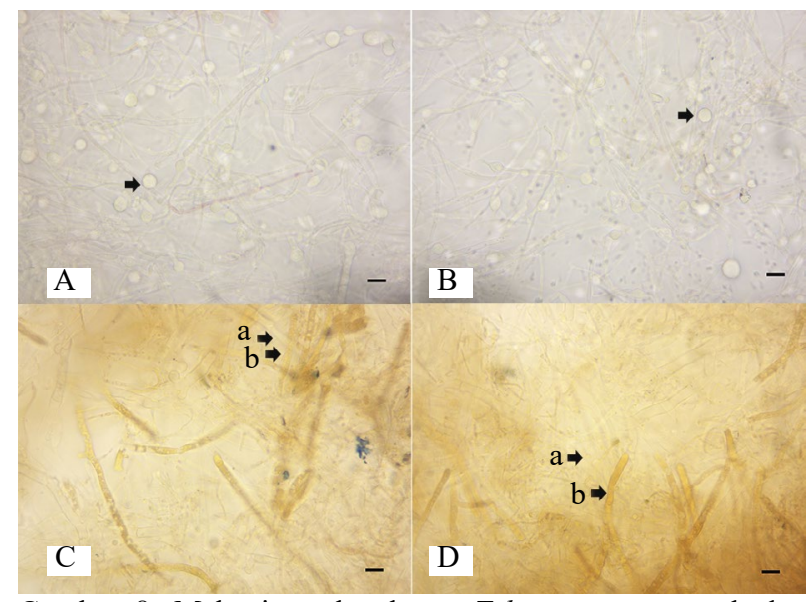

Gambar 8. Mekanisme hambatan Talaromyces sp. terhadap Fusarium oxysporum menghasilkan banyak klamidospora Fusarium oxysporum (A-B). Mekanisme penghambatan Talaromyces sp. terhadap Ganoderma boninense dengan cara hifa cendawan patogen (a) ditutupi oleh cendawan uji (b), (C-D). Garis skala $=10 \mu \mathrm{m}$

\section{PEMBAHASAN}

Cendawan hasil isolasi dari $H$. verticilliata merupakan cendawan yang umum ditemukan sebagai patogen (Shearer 2016). Pada penelitian ini Talaromyces sp., Gliomastix sp., dan Aspergillus kelompok flavi merupakan cendawan patogen yang berhasil diisolasi dari batang $H$. verticillata. Cendawan tersebut memiliki kemampuan untuk menghambat pertumbuhan cendawan patogen $F$. oxysporum dan G. boninense.

Cendawan patogen memiliki potensi sebagai cendawan antimikrob. Dwivedi dan Enespa (2013) melaporkan A.flavus dapat menghambat pertumbuhan F. oxysporum. Aspergillus flavus yang diisolasi dari buah cabai dapat menghambat pertumbuhan Colletotrichum capsici (Dharmaputra et al. 2015). Pada penelitian ini, Aspergillus kelompok flavi dapat

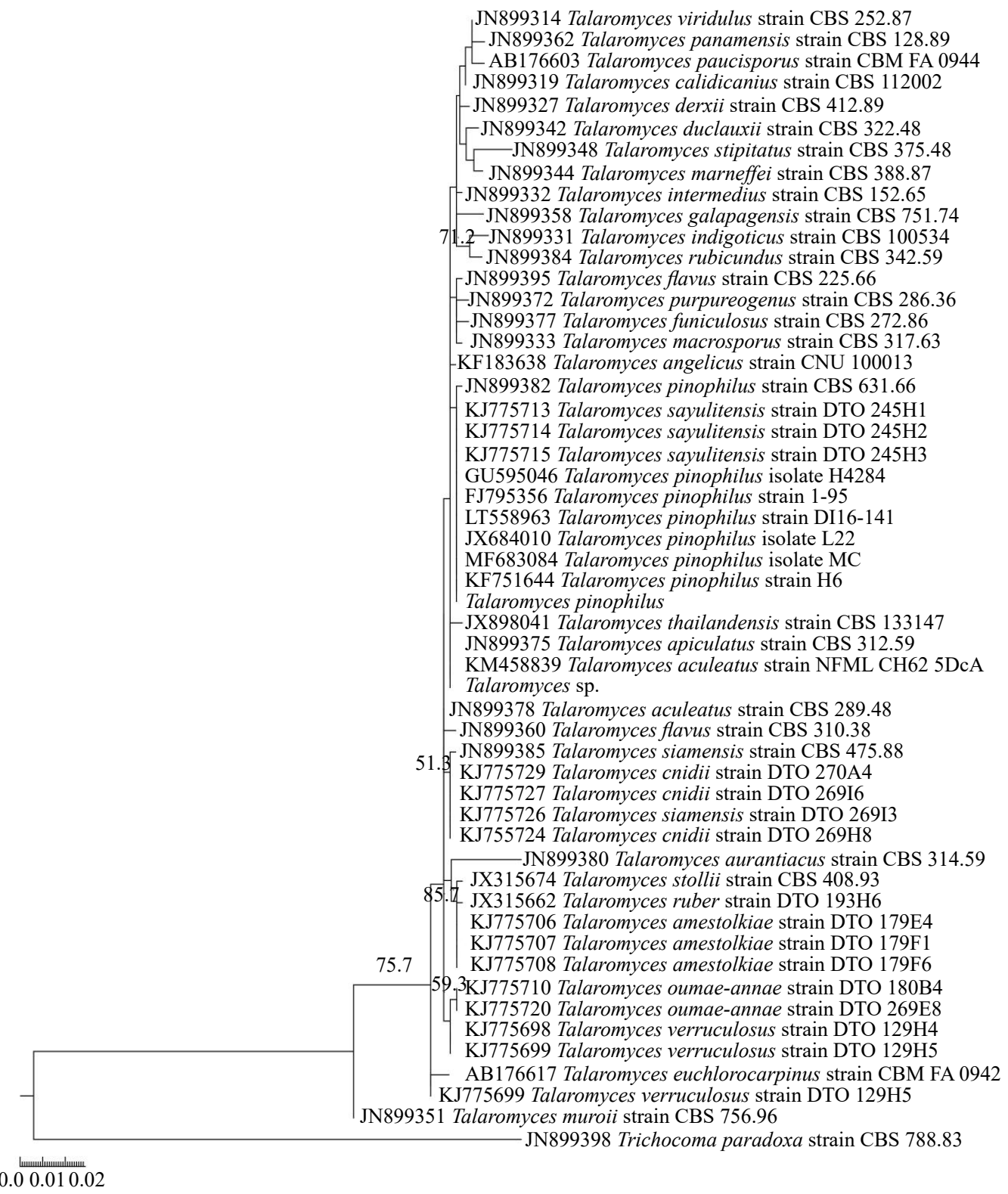

Gambar 9. Pohon filogeni isolat DLMB2 dan DM-4 dengan Trichocoma paradoxa sebagai outgroup, menggunakan model Tamura-3 parameter distribusi Gamma Invariant, Maximum Likelihood (ML) dengan 1000 bootstrap 
menghambat pertumbuhan $F$. oxysporum dan $G$. boninense. Pembentukan klamidospora merupakan mekanisme penghambatan yang dilakukan oleh $F$. oxysporum terhadap Aspergillus kelompok flavi. Klamidospora ialah spora aseksual yang berdinding tebal dan resisten terhadap lingkungan yang buruk. Trichoderma spp. merupakan salah satu cendawan patogen yang membentuk klamidospora di saat lingkungan kurang baik, miskin hara atau kekeringan dan berkembang kembali jika keadaan lingkungan sudah menguntungkan (Berlian et al. 2016).

Mekanisme penghambatan Gliomastix sp. terhadap pertumbuhan $F$. oxysporum dan $G$. boninense dengan cara antibiosis yang ditandai terbentuk zona kosong di antara cendawan uji dan patogen. Penghambatan tersebut juga mengakibatkan perubahan bentuk hifa patogen yaitu keriting. Antibiosis ialah kemampuan mikroorganisme dalam menghasilkan metabolit sekunder atau toksin penyebab lisis (Harman dan Kubicek 1998). Ergosterol dan benzofuranmetanol ialah metabolit sekunder yang dihasilkan oleh Gliomastix murorum yang digunakan sebagai antimikrob (Zhao et al. 2012). Ekstrak etil asetat Gliomastix polychroma dapat menghambat pertumbuhan Candida albicans yang resisten terhadap antifungal metisilin sehingga dapat dijadikan sebagai obat baru dalam bidang farmasi (Rao et al. 2015). Mikroorganisme antagonis dapat digunakan sebagai agen pengendali hayati dengan syarat memiliki kemampuan beradaptasi terhadap kondisi lingkungan yang nutrisinya rendah, tidak menyebabkan penyakit pada inang, tidak menghasilkan metabolit berbahaya, dan efektif melawan patogen dengan kisaran inang yang luas (Dharmaputra et al. 2015).

Pertumbuhan Talaromyces sp. menekan pertumbuhan cendawan patogen. Mekanisme interaksi yang terjadi antara Talaromyces sp. dengan $G$. boninense dan $F$. oxysporum ialah kompetisi dan parasitisme. Pengamatan secara mikroskopis menunjukkan bahwa hifa Talaromyces sp. melilit dan menutupi hifa $G$. boninense, sedangkan pada $F$. oxysporum membentuk klamidospora. Mekanisme penghambatan secara kompetisi terjadi apabila cendawan uji menutupi cendawan patogen dan pertumbuhan cendawan uji lebih cepat dibandingkan dengan cendawan patogen, sedangkan mekanisme parasitisme ditunjukkan dengan hifa cendawan uji tumbuh di atas hifa cendawan patogen (Porter 1942; Skidmore and Dickinson 1976). Kompetisi antara cendawan uji dan patogen menyebabkan cendawan patogen tidak memiliki ruang untuk hidup, sehingga pertumbuhan cendawan patogen menjadi terhambat (Octriana 2011). Dezfooli et al. (2014) melaporkan mekanisme penghambatan kompetisi oleh T. flavus dan Trichoderma harzianum dapat menghambat pertumbuhan F. oxysporum f. sp. lycopersici penyebab layu pada tanaman tomat. Cendawan yang memiliki mekanisme penghambatan kompetisi dan parasitisme, umumnya memiliki spektrum penghambatan yang lebih luas dan kuat (Amaria et al. 2015). Hal tersebut didukung oleh persentase hambatan yang paling tinggi di antara cendawan uji dengan patogen ialah penghambatan yang dilakukan oleh Talaromyces sp.

Hasil analisis pohon filogenetik daerah ITS menunjukkan Talaromyces sp. berada satu grup dengan T. aculeatus NFML CH62 5DcA (nomor aksesi KM458839), T. apiculatus CBS 312.59 (nomor aksesi JN899375), dan T. thailandensis (nomor aksesi JX898041). Dari India dengan tingkat kepercayaan di bawah $50 \%$. Rendahnya nilai tingkat kepercayaan yaitu dibawah $95 \%$ belum cukup untuk mendeskripsikan Talaromyces sp. hingga ke tingkat spesies (Felsenstein 1985) sehingga dibutuhkan analisis multigen untuk dapat mengidentifikasi cendawan tersebut. Visagie et al. (2014) menggunakan gen beta-tubulin untuk menganalisis Talaromyces hingga tingkat spesies.

Berdasarkan hasil penelitian dapat disimpulkan bahwa cendawan yang diisolasi dari $H$. verticilliata ialah cendawan patogen yang terdiri atas Talaromyces sp., Gliomastix sp., dan Aspergillus kelompok flavi. Cendawan tersebut memiliki kemampuan untuk menghambat pertumbuhan cendawan patogen $F$. oxysporum dan $G$. boninense. Hasil uji antagonisme menunjukkan hanya Talaromyces sp. persentase daya hambat tertinggi terhadap cendawan patogen. Analisis molekuler dilakukan terhadap cendawan terpilih yaitu Talaromyces sp. untuk dapat mengidentifikasi hingga ke tingkat spesies. Berdasarkan hasil BLAST menunjukkan Talaromyces sp. memiliki kemiripan 99\% dengan T. aculeatus, akan tetapi analisis filogenetik daerah ITS menunjukkan Talaromyces sp. membentuk spesies kompleks dengan T. aculeatus, $T$. apiculatus, dan $T$. thailandensis dengan nilai tingkat kepercayaan di bawah 50\%. Hasil tersebut menunjukkan bahwa penggunaan gen ITS untuk mengidentifikasi Talaromyces sp. hingga ke tingkat spesies belum dapat digunakan sehingga diperlukan gen tambahan untuk mengidentifikasi Talaromyces sp. yaitu gen beta-tubulin.

\section{UCAPAN TERIMA KASIH}

Penulis menyampaikan ucapan terima kasih pada Kementerian Riset dan Teknologi DIKTI atas dana penelitian yang diberikan melalui program Beasiswa Pendidikan Pascasarjana Dalam Negeri 2013. 


\section{DAFTAR PUSTAKA}

Alix MS, Scribailo RW, Price JD. 2009. Hydrilla verticillata (Hydrocharitaceae): an undesirable addition to Indiana's aquatic flora. Rhodora 111:131-136.

Amaria W, Harni R, Samsudin. 2015. Evaluation of antagonistic fungi in inhibiting the growth of Rigidoporus microporus causing white root disease in rubber plants. J TIDP 2:51-60.

Berlian I, Anarqi S, Pudjihartati E. 2016. Isolasi, identifikasi, dan antagonisme in vitro isolat Trichoderma spp. asal kebun karet, Blimbing, Pekalongan, Jawa Tengah. Jurnal Penelitian Karet 34:201-212.

Daryanto 2004. Laporan Perkembangan Penyakit Layu Pisang. Jakarta: Direktorat Perlindungan Tanaman Hortikultura.

Dezfooli RA, Naraghi L, Niazmand A. 2014. A comparative study on different antagonistic mechanisms of Talaromyces flavus and Trichoderma harzianum in terms of growth inhibition on Fusarium oxysporum f. sp. lycopersici, causal agent of tomato wilt disease in laboratory condition. International Journal of Agricultural Research and Review 2:115-127.

Dharmaputra OS, Sudirman LI, Fitriani M. 2015. Mikobiota pada buah cabai untuk pengendali hayati Colletotrichum capsici. Jurnal Fitopatologi Indonesia 11:150-158.

Dwivedi SK, Enespa. 2013. In vitro efficacy of some fungal antagonists against Fusarium solani and Fusarium oxysporum f. sp. Lycopersici causing brinjal and tomato wilt. International Journal of Biological and Pharmaceutical Research 4:46-52.

Filip P, Weber RWS, Sterner O, Anke T. 2003. Hormonemate, a new cytotoxic and apoptosis inducing compound from the endophytic fungus Hormonema dematioides. Identification of the producing strain, isolation and biological properties of hormonemate. Z. Naturforsch 58:547-552.

Felsenstein J. 1985. Confidence limits on phylogenies: an approach using the bootstrap. Evolution 39:783-791.

Fokkema NJ. 1978. Fungal antagonism in the phylosphere. Ann Appl Biol 89:115-117.

Ginting C, Maryono T. 2012. Penurunan keparahan penyakit busuk pangkal batang pada lada akibat aplikasi bahan organik dan Trichoderma harzianum. J HPT Tropika 12:162-168.

Harman GE, Kubicek CP. 1998. Trichoderma and Gliocladium Enzymes Biological Control and Commercial Applications Volume 2. London: Taylor and Francis.

Langeland KA. 1996. Hydrilla verticillata (L.f.) Royle (Hydrocharitaceae), "the perfect aquatic weed". Castanea 61:293-304.

Nelson PE. 1993. Taxonomy of Fungi in the Genus Fusarium with Emphasis on Fusarium oxysporum. Fusarium Wilt of Banana. The American Phytopathological Society, St. Paul, Minnesota: APS Press.
Octriana L. 2011. Potensi agen hayati dalam menghambat pertumbuhan Phytium sp. secara in vitro. Buletin Plasma Nutfah 17:138-142.

Porter CL. 1942. Concerning the characters of certain fungi as exhibited by their growth in the presence of other fungi. AMJ Bot 11:168-188.

Priwiratama H, Prasetyo AE, Susanto A. 2014. Pengendalian penyakit busuk pangkal batang kelapa sawit secara kultur teknis. Jurnal Fitopatologi Indonesia 10:1-7.

Rao HCY, Baker S, Rakshith D, Satish S. 2015. Molecular profiling and antimicrobial potential of endophytic Gliomastix polychroma CLB32 inhabiting Combretum latifolium Blume. Mycology 6:176-181.

Sa'id EG. 1994. Dampak negatif pestisida, sebuah catatan bagi kita semua. Agrotek 2:71-72.

Seifert K, Morgan JG, Gams W, Kendrick B. 2011. The Genera of Hyphomycetes. Utrecht: CBS-KNAW Fungal Biodiversity Centre.

Shabana YM, Charudattan R. 1996. Microorganisms associated with Hydrilla in ponds and lakes in North Florida. $J$ Aquat Plant Manage 34:60-68.

Shearer JF. 2016. Surveys for Phatogens of Monoecious Hydrilla. APCRP Technical Notes Collection. ERDC/ TN APCRP-BC-38. Vicksburg: Army Engineer Research and Development Center.

Skidmore AM, Dickinson CH. 1976. Colony interactiona and hyphal interference between Septoria nodorum and phylloplane fungi. Trans Brit Mycol Soc 66:57-64.

Susanto A, Prasetyo AE, Wening S. 2013. Laju infeksi Ganoderma pada empat kelas tekstur tanah. J Fitopatol Indones 9:39-46.

Tamura K, Peterson D, Peterson N, Stetcher G, Nei M, Kumar S. 2011. MEGA5: molecular evolutionary genetics analysis using maximum likelihood, evolutionary distance, and maximum parsimony methods. Molecular Biology and Evolution 28:2731-2739.

Visagie CM, Hirooka Y, Tanney JB, Whitfield E, Mwange K, Meijer M, Asmend AS, Seifert KA, Samson RA. 2014. Aspergillus, Penicillium, and Talaromyces isolated from house dust samples collected around the world. Studies in Mycology 78:63-139.

White TJ, Bruns T, Lee S, Taylor J. 1990. Amplification and Direct Sequencing of Fungal Ribosomal RNA Genes for Phylogenetics. New York: Academic Pr.

Zhao J, Sun W, Shan T, Mou Y, Lou J, Li Y, Wang M, Zhou L. 2012. Antimicrobial metabolites from the endophytic fungus Gliomastix murorum Ppf8 associated with the medicinal plant Paris polyphylla var. yunnanensis. Journal of Medicinal Plants Research 6:2100-2104. 